\title{
The Influence of the Label on the Quality of a Solid-Phase Immunoassay: Evaluation of a Commercial ELISA Kit for Serum Ferritin
}

\author{
By H. A. Assink, H.J. Brouwer, B. G. Blijenberg and B. Leijnse \\ Department of Clinical Chemistry, University Hospital Rotterdam-Dijkzigt and Department of Chemical \\ Pathology, Erasmus University, Rotterdam, The Netherlands
}

(Received February 11/June 6, 1983)

Summary: A new Enzyme Linked Immuno Sorbent Assay (ELISA) kit for the determination of serum ferritin has been compared with another ferritin kit based on the Immuno Radio-Metric Assay (IRMA) approach, both assays containing similar antibodies.

Based on these studies, we found the within-run precision of the ELISA (and IRMA) to have coefficients of variation of $4-10 \%$ and $2-6 \%$ respectively, over a concentration range of $12-600 \mu \mathrm{g} / \mathrm{l}$. The between-run precision for the same concentration range exhibited a CV range of $9-13 \%$ and $7-11 \%$ respectively. The sensitivities were found to be $1.4 \mu \mathrm{g} / 1$ and $0.9 \mu \mathrm{g} / \mathrm{l}$. The mean recovery was $103 \%$ for the ELISA procedure.

It was found that, using the serum dilution technique, the linearity reached to $1000 \mu \mathrm{g} / \mathrm{l}$.

In the ELISA procedure no influence from the so-called "high dose hook effect" was observed. While EDTA-plasma produced $6 \%$ lower values than serum in the ELISA technique, no interference from albumin, $\gamma$-globulins and mild haemolysis was observed. Stability problems with the ELISA kit were not encountered. A comparative analysis of multiple specimens demonstrated nearly identical values with $r=0.994$ and $\mathrm{y}=0.87 \mathrm{x}^{1.01}$.

The quality and ease of operation of the ELISA approach compared with other techniques are discussed. In conclusion it is possible to replace a radio-label in an immunoassay with an enzyme-label with the same degree of reliability and other parameters of quality control exhibited by radioimmunoassays.

Einfluß der Markers auf die Qualität eines Festphasen-Immunassay: Prüfung eines käuflichen ELISA-Bestecks für Ferritin im Serum

Zusammenfassüng: Ein neues Enzymimmunoassay(ELISA)-Besteck für die Bestimmung von Ferritin im Serum wurde mit einem Ferritin-Besteck nach dem Prinzip des immunradiometrischenAssay (IRMA) verglichen; beide Bestecks enthielten ähnliche Antikörper.

Für die Präzision in der Serie fanden wir für einen Konzentrationsbereich von. $12-600 \mu \mathrm{g} / \mathrm{l}$ Variationskoeffiziénteñ von $4-10 \%$ (ELISA) und 2-6\% (IRMA), für die Präzision von Tag zu Tag 9-13\% bzw. 7-11\%. Die Empfindlichkeit war 1,4 bzw. 0,9 $\mu \mathrm{g} / \mathrm{l}$. Die mittlere Wiederfindung betrug für das ELISA-Verfahren $103 \%$. Die Linearität untersucht durch Verdünnungstechnik reichte bis $1000 \mu \mathrm{g} / \mathrm{l}$. Bei dem ELISA-Verfahren wurde kein Einfluß durch den sog. ,high dose hook effect“ beobachtet. Während EDTA-Plasma mit dem ELISA-Verfahren $6 \%$ niedrigere Werte als Serum ergab, bestand kein Einfluß von Albumin, $\gamma$-Globulinen oder geringe Hämolyse.

Haltbarkeitsprobleme mit dem ELISA-Besteck ergaben sich nicht. Die Vergleichsanalyse an einer Vielzahl von Proben ergab nahezu identische Werte mit $r=0,994$ und $y=0,87 x^{1,01}$. Die Qualität und Arbeitsweise des Enzymimmunasșays wird im Vergleich mit anderen Verfahren diskutiert. 
Zusammenfassend stellen wir fest, daß es möglich ist, die Radiomarkierung im Immunassay mit dem selben Grad an Zuverlässigkeit und anderer Qualitätskontroll-Kenngrößen von Radioimmunassays durch eine Enzymmarkierung zu ersetzen.

\section{Introduction}

Ferritin is the major storage protein of iron in the body. It is located mainly in the reticuloendothelial system and is found predominantly in the liver, spleen and bone marrow. The mean serum ferritin concentration correlates quite well with the total body iron store in clinical conditions ranging from iron deficiency to iron overload. Increased serum ferritin levels can also be found in patients with some types of malignancy, liver disease and inflammation $(1-4)$.

The first immunoassay sensitive enough to detect ferritin in normal serum was developed by Addison et al. in 1972 (5). In their assay, they employed an immunosorbent and ${ }^{125}$ I-labeled anti-ferritin antibody and termed the technique an immunoradiometric assay (IRMA) to distinguish it from typical radioimmunoassays. Within 2 years, Miles et al. introduced an improved and simpler assay, which they designated as a "two-side IRMA" (6) and numerous commercial kits have been developed based on this principle. With the preparation of highly purified ferritin it then became possible to develop a conventional radioimmunoassay (RIA) utilizing ${ }^{125} \mathrm{I}$-labeled ferritin (7). Since RIA and IRMA methodologies suffer from similar disadvantages (e.g., short reagent shelf lives, special requirements and restrictions for handling radioisotopes, radioactive waste disposal problems and the need for sophisticated gamma counting equipment) the development of suitable enzyme immunoassays was welcomed as a great advance in clinical chemistry (8-14).

Although the first enzyme immunoassays developed did not achieve the precision and the sensitivity shared by RIA and IRMA techniques $(8,9,12)$, later improvements in assay design enable them to compete with the radiometric assays $(10,11,13,14)$. Ferritin enzyme immunoassays have now become commercially available (15).

An ELISA method has recently been developed by the manufacturer of an IRMA kit; similar antibodies are used in both kits. We have evaluated the quality of this new ELISA.

\section{Materials and Methods}

Ferritin assay systems

We used IRMA kits from Behringwerke AG, Marburg, Germany (RIA-gnost ${ }^{\circledR}$ Ferritin) and from Ramco Laboratories, Houston
Texas 77098, USA (Fer-iron $\left.{ }^{(}\right)$and an ELISA kit from Ramco Laboratories (Spectro Ferritin ${ }^{\circledast}$ ) for this study.

\section{RIA-gnos? Ferritin}

An evaluation has been reported by Thornton \& Waters (16). We performed the assay according to the package insert instructions. The sample requirement for a single assay is $100 \mu \mathrm{l}$, but to com= pensate for limited linearity, we used $\overline{50} \mu \mathrm{l}$. Data reduction is performed by means of a weighted linear regression using a logit-log calculation (17). We utilized a computer program capable of curve-fitting and rejecting those results falling outside the $95 \%$ confidence range of the regression line. The kit's expiration date is generally about 7 weeks after delivery.

\section{Fer-iron ${ }^{8}$}

This commercial assay is similar in its design to that described by Miles et al. (6).

Depending on he actual procedure used, the required sample volume for a single determination is either 10 or $20 \mu \mathrm{l}$. The total minimum incubation time consists of either 4 hours or 90 minutes and for our evaluation we employed the 4 hour procedure. For the calculation of the results the manufacturer recommends the logitlog method, and we performed this calculation with the aid of the computerized weighted logit-log program. The kit has a shelf life of about 12 weeks when stored at $2-8^{\circ} \mathrm{C}$.

\section{Spectro Ferritin ${ }^{\circledR}$}

This kit is identical to the Fer-iron ${ }^{\text {क }}$ kit with the exception that the alkaline phosphatase label and the substrate $p$-nitrophenyl phosphate have replaced the radioisotope. We carried out the assay essentially as recommended by the manufacturer. However, the manufacturer points out that the investigator has the option of varying the incubation period as with the Fer-iron ${ }^{\circledR}$ assay. We employed for our study a sample volume of $10 \mu \mathrm{l}$ and a total incubation time of 4.5 hours. We calculated the results using the same computer searching logit-log program as we employed for the IRMA approach. The kit expires in about 10 months.

Sample handling

All samples are kept frozen at $-20^{\circ} \mathrm{C}$ until analysis.

\section{Results}

\section{Standard curve}

Figure 1 represents the mean of 36 standard curves of Spectro Ferritin ${ }^{\circledR}$ obtained in our evaluation. We observed differences between the four lot numbers tested (001, 003, 004 and 005) with lot 003 exhibiting high absorbance values (up to $A=2.000$ for the $2000 \mu \mathrm{g} / \mathrm{l}$ standard). This finding was confirmed by the manufacturer and an improvement was then made by using a shorter incubation períiod for the determination of enzyme activity. Lot 001 frequently showed poor duplication of the $2000 \mu \mathrm{g} / \mathrm{l}$ standard with absorbance differences up to $0.400 \mathrm{~A}$. We observed an improvement with the Qther lot numbers. 


\section{Walter de Gruyter Berlin.New York}

\section{E. Buddecke \\ Biochemische Grundlagen der Zahnmedizin}

$17 \mathrm{~cm} \times 24$ cm. XV, 193 Seiten. 90 Abbildungen. 19 Tabellen. 1981. Flexibler Einband. DM 36,- ISBN 3110087383

Das Kurzlehrbuch für Zahnärzte und Studierende behandelt die Biochemie der Zähne, des Zahnhalteapparates und der Mundhöhle. Es werden Chemie und Stoffwechsel der organischen Matrix der Zahnhartsubstanz, Biomineralisation, Fluoridstoffwechsel und die spezielle Biochemie des Speichels und der Mikroorganismen der Mundhöhle beschrieben. Sie bilden die Grundlage für die Pathobiochemie der beiden häufigsten Erkrankungen der Odontologie - der Karies und der Parodontópathie. Die Darstellung umfaßt neben pathogenetischen auch präventive Aspekte der Karies und Parodontopathie sowie eine Übersicht über die chemische Zusammensetzung und Wirkungswèise von Żahnpflegemitteln.

Der behandelte Inhalt des Buches berücksichtigt auch die Prüfungsordnung für Żahnärzté.

\section{Aus dem Inhhalt (Hauptkàpitel):}

Zahnmedizin und Biochemie $\cdot$ Chemie der anorganisçhen und organischen Bestandteile der Zahnhartgewebe · Stoffwechsel der organischen Matrix von Zähnen und Knochen - Biomineralisation Regulation des Hartgèwebestoffwechsels - Topochemie der Zahn hartgewebe - Biochemie des Fluors : Speicheldrüsen und Speichèl -Mikroorganismen der Mundhöhle ·

Pathobiochemie der Karies .

Kariesabwehr und Kariesprophylaxe · Gingiva, Parodont und Parodontopathie Chemische Zusammensetzung von Zahnpflegemitteln - Mundhöhle und Allgemeinstoffwechsel.

\section{So können Sie die} PMN Elastase bestimmen.

Bei entzündlichen Prozessen ist Elastase aus polymorphnucleären Leukozyten (PMN Elastase) eine krankheitsverștärkende Noxe.

Ihre Bestimmung erlaubt eine frühzeitige Erkennung und eine direkte Verlaufskontrolle einer Entzündung.

Sie wird bestimmt mit dem Merck Immunoassay PMN Elastase, der den Komplex aus PMN Elastase und $\alpha_{1}$-Proteinaseinhibitor erfaßt.

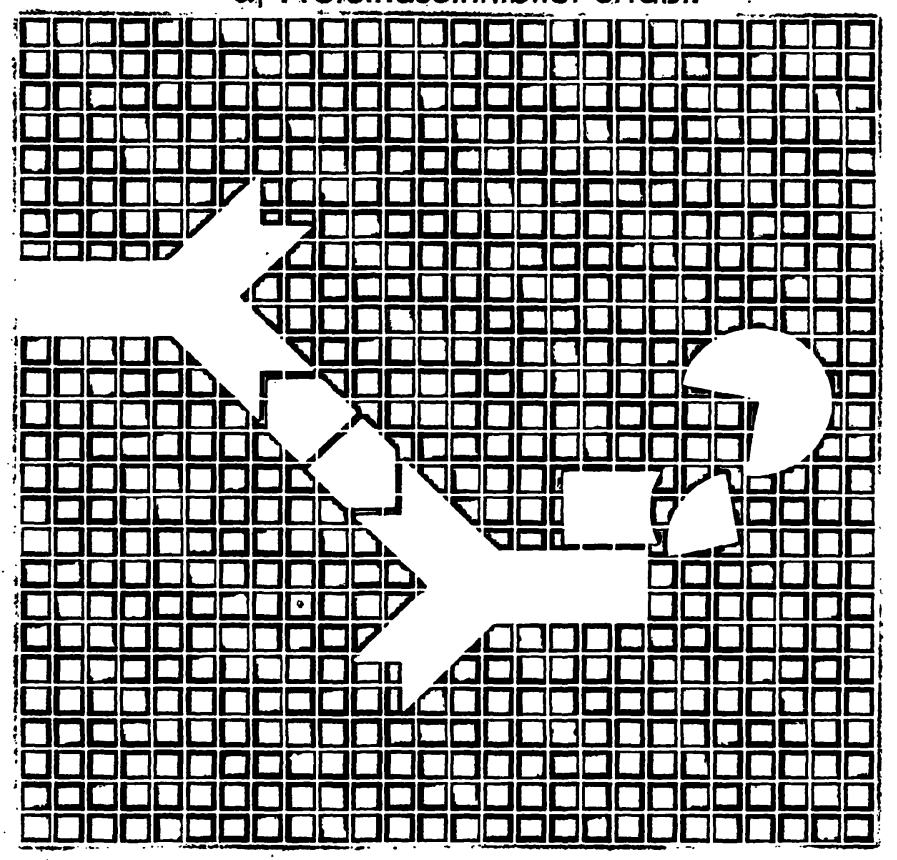

Es handelt sich um einen Festphasenimmunoassay nach dem Sandwich Prinzip, der in jedem Labor durchgeführt werden kann.

PMN Elastase - die neve Dimension in der Entzündungsdiagnostik.

Weitere Informationen sendẹn wir Ihnen auf Wụnsch gerne zu. 


\section{Walter de Gruyter Berlin·New York}

\section{K. Fotherby S. B. Pal (Editors)}

\section{K. Agarwal (Editor)}

\section{Hormones in Normal and" Abnormal Human Tissues}

\section{Volume 1}

$1980.17 \mathrm{~cm} \times 24 \mathrm{~cm} . \mathrm{XIV}, 658$ pages with figures and tables. Hardcover. DM 145,-; approx. US $\$ 69.25$

ISBN 3110080311

\section{Volume 2}

$1981.17 \mathrm{~cm} \times 24 \mathrm{~cm}$. XII, 552 pages with figures and täbles.

Hardcover. DM 135,-; approx. US $\$ 64.50$

ISBN 3110085410

\section{Volume 3}

1982. $17 \mathrm{~cm} \times 24 \mathrm{~cm}$. Approx. 500 pages with figures and tables. Hardcover. Approx. DM 120,-; approx. US $\$ 57.25$ ISBN 3110086166

Hormones in Normal and Abnormal Human Tissues is a threevolume monograph dealing with the circulating levels, the pathological and therapeutic conditions and the factors controlling the secretion of non-polypeptide, protein and steroid hormones.

An attempt has been made to place emphasis on the concentration of the various hormones in tissues; where they are produced and where they might localize and produce an effect, and how these levels are modified under various circumstances.

\section{Hormone Antagonists}

$1982.17 \mathrm{~cm} \times 24 \mathrm{~cm}$. IX, 734 päges. Numerous illustrations. Hardcover. DM 180,-; approx. US $\$ 85.75$ ISBN 3110086131

This book groups together under one single cover antagonists for those hormones where antagonism has been documented specifically and with a certain degree of certitude. The major emphasis has been delineation of anti-hormone activity at the level of the hormone receptor but other aspects, such as antibody mediated antagonism and inhibition of synthesis, have been included to indicate other possible levels of inhibition of hormone activity. Clinical aspects, too, have been covered where they were documented with certitude.

It is felt that the book represents a major new reference source for years to come. Scientists, medical academicians, and advanced graduate students may use the book as a departing point for further pursuit of their own field. Involved research workers will find the volume of much interest since it provides data not published elsewhere. The book may also be used as a text volume to indicate the diversity and the wealth of information on the subject of hormone antagonism both in the basic research and in clinical medicine. Photo-offset method of publication assures expediency before specialized articles obsolete novelty. 


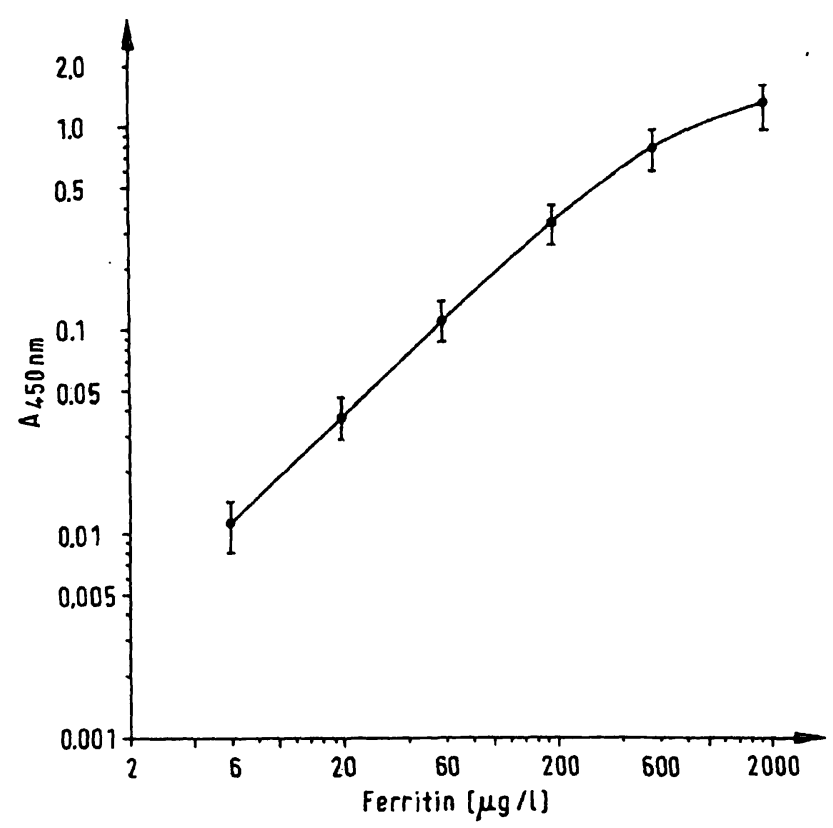

Fig. 1. Standard curve of Spectro Ferritin (ELISA). This curve is the mean of 36 standard curves $\pm S D$.
Upon storage of the kits the absorbance values decreased gradually (by $5-20 \%$ up to the expiry date), but without any detectable influence on the results. Further stability problems were not encountered.

\section{Sensitivity}

We evaluated sensitivity in terms of "lowest detection limit", as defined by Schuurs \& Van Weemen (18). In one assay we evaluated 20 zeros in duplicate and determined the sensitivity by calculating the $95 \%$ confidence limits at the zero point of the standard curve.

Based on this approach, we found the sensitivity for the Spectro Ferritin ${ }^{\circledR}$ to be $1.4 \mu \mathrm{g} / \mathrm{l}$, corresponding to $14 \mathrm{pg}$ per bead, with the assay requiring $10 \mu \mathrm{l}$ serum. Fer-iron ${ }^{\circledR}$ has a sensitivity of $0.9 \mu \mathrm{g} /$, corresponding to $9 \mathrm{pg}$ per bead.

\section{Precision}

We performed precision studies using serum pools containing low, normal and high ferritin levels (tab. 1).

Tab. 1. Precision data.

\begin{tabular}{|c|c|c|c|c|c|c|c|c|c|c|c|c|}
\hline & \multicolumn{4}{|c|}{ Spectro Ferritin } & \multicolumn{4}{|c|}{ Fer-iron } & \multicolumn{4}{|c|}{ RIA-gnost ${ }^{\circledR}$} \\
\hline & $\mathbf{n}$ & $\begin{array}{l}\text { Mean } \\
(\mu \mathrm{g} / \mathrm{l})\end{array}$ & $\pm \mathrm{SD}$ & $\begin{array}{l}\text { CV } \\
(\%)\end{array}$ & $\mathbf{n}$ & $\begin{array}{l}\text { Mean } \\
(\mu g / l)\end{array}$ & $\pm \mathrm{SD}$ & $\begin{array}{l}\mathrm{CV} \\
(\%)\end{array}$ & $\mathrm{n}$ & $\begin{array}{l}\text { Mean } \\
(\mu \mathrm{g} / \mathrm{l})\end{array}$ & $\pm \mathrm{SD}$ & $\begin{array}{l}\mathrm{CV} \\
(\%)\end{array}$ \\
\hline & \multicolumn{12}{|c|}{ Within-run } \\
\hline $\begin{array}{l}\text { Pool I } \\
\text { Pool II } \\
\text { Pool III }\end{array}$ & $\begin{array}{l}20 \\
20 \\
20\end{array}$ & $\begin{array}{l}12.2 \\
77.3 \\
515\end{array}$ & $\begin{array}{c}1.21 \\
2.81 \\
37.2\end{array}$ & $\begin{array}{l}9.9 \\
3.6 \\
7.2\end{array}$ & $\begin{array}{l}20 \\
20 \\
20\end{array}$ & $\begin{array}{l}12.1 \\
86.7 \\
691\end{array}$ & $\begin{array}{r}0.67 \\
2.11 \\
32.4\end{array}$ & $\begin{array}{l}5.6 \\
2.4 \\
4.7\end{array}$ & $\begin{array}{l}20 \\
20 \\
-\end{array}$ & $\begin{aligned} & 42.7 \\
& 235 \\
> & 500\end{aligned}$ & $\begin{array}{l}2.30 \\
26.8 \\
-\end{array}$ & $\begin{array}{r}5.4 \\
11.4 \\
-\end{array}$ \\
\hline Pool III & \multicolumn{12}{|c|}{ Between-run } \\
\hline $\begin{array}{l}\text { Pool I } \\
\text { Pool II } \\
\text { Pool III }\end{array}$ & $\begin{array}{l}20 \\
20 \\
20\end{array}$ & $\begin{array}{l}11.9 \\
85.9 \\
618\end{array}$ & $\begin{array}{c}1.42 \\
7.66 \\
75.8\end{array}$ & $\begin{array}{r}11.9 \\
8.9 \\
13.3\end{array}$ & $\begin{array}{r}8 \\
10 \\
10 \\
(9\end{array}$ & $\begin{array}{l}13.2 \\
89.7 \\
720 \\
624\end{array}$ & $\begin{array}{l}1.41 \\
10.14 \\
50.1 \\
45.8\end{array}$ & $\begin{array}{l}10.7 \\
11.3 \\
6.9 \\
7.3)^{\mathrm{a}}\end{array}$ & $\begin{array}{l}10 \\
10 \\
-\end{array}$ & $\begin{array}{c}34.6 \\
172 \\
>500\end{array}$ & $\begin{array}{l}4.01 \\
9.7 \\
-\end{array}$ & $\begin{array}{r}11.6 \\
5.7 \\
-\end{array}$ \\
\hline
\end{tabular}

a Values obtained after manual construction of the standard curves and recalculation of the results.

Tab. 2. Differences in the results of Spectro Ferritinin ${ }^{\otimes}$ and Feriron ${ }^{\circledR}$.

\begin{tabular}{lllll}
\hline & Pool I & Pool II & Pool III \\
\hline $\begin{array}{l}\text { Differences of } \\
\text { the means }(\mu \mathrm{g} / \mathrm{l})\end{array}$ & 1.3 & 3.8 & 102 & $(6)^{\mathrm{a}}$ \\
$\begin{array}{l}\text { 95\% confidence } \\
\text { interval for the } \\
\text { differences }(\mu \mathrm{g} / \mathrm{l})^{\mathrm{b}}\end{array}$ & $0.1-2.5$ & $-3.6-11.2$ & $\begin{array}{c}54-150 \\
(-40-52)\end{array}$ \\
\hline
\end{tabular}

a Values obtained after manual construction of the standard curves and recalculation of the results.

b Calculated with use of the Student's t-test $(p=0: 05)$.
With Fer-iron ${ }^{\circledR}$ we obtained a considerable higher mean value for pool serum III than with Spectro Ferritin $^{\circledR}$. This is a result of the fact that the $600 \mu \mathrm{g} / \mathrm{A}$ standard does not exactly fit the linear regression line of the logit-log calculation method for Feriron ${ }^{\circledR}$. This standard point lies in most cases above the standard curve, causing an overestimation in that area. We have reconstructed the standard curves manually so that standard point $600 \mu \mathrm{g} / \mathrm{l}$ fitted the curves and recalculated the values for serum pool III. This results in a mean ferritin concentration of $624 \mu \mathrm{g} /$ instead of $720 \mu \mathrm{g} / \mathrm{l}$ (tab. 2). 


\section{Recovery}

Recovery studies have been performed by adding ferritin standards to sera with different ferritin concentrations. The recovery study results are expressed as the relative amount of added ferritin found after assay determination. The average recovery was 103 $\pm 13 \%(n=17)$ for a final concentration range of $28-1950 \mu \mathrm{g} /$.

\section{Linearity}

The serum pools containing serially diluted (11-fold) normal and high ferritin levels were also analysed in separate runs. The assay results are listed in table 3 .

Dilution of the highest standard $(2000 \mu \mathrm{g} / \mathrm{l})$ showed good linearity and parallelism when compared with the standard curve (fig. 2). Dilution of serum samples does not result in a significant deviation from parallelism in comparison with the standard curve, except in the high dose region (fig. 2). Some serum

Tab. 3. Ferritin concentration at dilution. ${ }^{\mathrm{a}}$

\begin{tabular}{|c|c|c|}
\hline & \multicolumn{2}{|c|}{ Spectro Ferritin ${ }^{\circledR}$} \\
\hline & Pool II & Pool III \\
\hline & $\begin{array}{l}\text { Mean } \pm S D \\
(\mu \mathrm{g} / \mathrm{l})\end{array}$ & $\begin{array}{l}\text { Mean } \pm S D \\
(\mu \mathrm{g} / \mathrm{l})\end{array}$ \\
\hline Undiluted & $85.9 \pm 7.66$ & $618 \pm 75.8$ \\
\hline 11-fold diluted & $94.5 \pm 14.40$ & $636 \pm 68.3$ \\
\hline $\begin{array}{l}\text { Difference } \\
\text { of the means }\end{array}$ & 8.6 & 18 \\
\hline $\begin{array}{l}95 \% \text { confidence } \\
\text { interval for the } \\
\text { difference }\end{array}$ & $2.2-15.4$ & $-22-62$ \\
\hline \multirow[t]{4}{*}{$\mathrm{n}$} & 20 & 20 \\
\hline & \multicolumn{2}{|l|}{ Fer-iron ${ }^{\circledR}$} \\
\hline & Pool II & Pool III \\
\hline & $\begin{array}{l}\text { Mean } \pm S D \\
(\mu \mathrm{g} / \mathrm{l})\end{array}$ & $\begin{array}{l}\text { Mean } \pm S D \\
(\mu g / l)\end{array}$ \\
\hline Undiluted & $89.7 \pm 10.14$ & $720 \pm 50.1(624 \pm 45.8)^{b}$ \\
\hline 11-fold diluted & $109.9 \pm 6.05$ & $635 \pm 46.0$ \\
\hline $\begin{array}{l}\text { Difference } \\
\text { of the means }\end{array}$ & 20.2 & $85 \quad(11)$ \\
\hline $\begin{array}{l}95 \% \text { confidence } \\
\text { interval for the } \\
\text { difference }\end{array}$ & $\begin{array}{c}9.7-30.7 \\
.\end{array}$ & $54-116(-32-54)$ \\
\hline $\mathbf{n}$ & 10 & 10 \\
\hline
\end{tabular}

a Values obtained for the diluted samples are corrected for dilution. The confidence intervals are calculated with use of Student's t-test for paired samples at $\mathrm{p}=0.05$.

b Values obtained after manual construction of the standard curves and recalculation of the results.

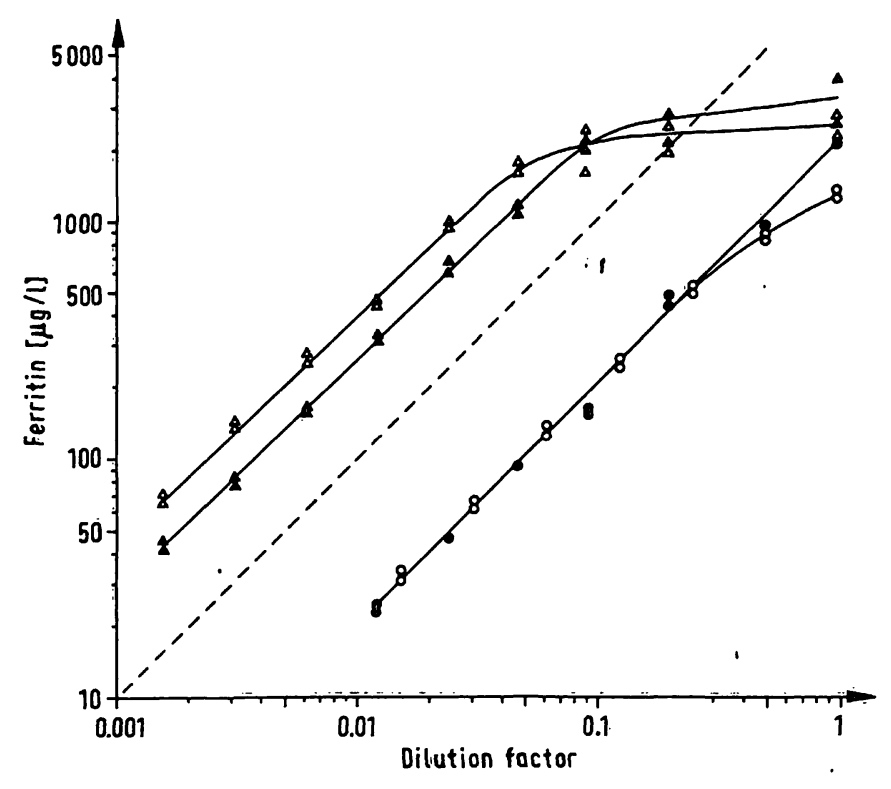

Fig. 2. Linearity of Spectro Ferritin ${ }^{\otimes}$. Dilution of a high standard and patient sera. Standard, $2000 \mu \mathrm{g} /(\boldsymbol{\theta})$; serum sampl, $40000 \mu \mathrm{g} / \mathrm{l}(\Delta)$; serum sample, $25000 \mu \mathrm{g} / \mathrm{l}(\Delta)$; serum sample, $2050 \mu \mathrm{g} / \mathrm{l}(\mathrm{O})$. Dilutions must parallel the dotted line $(--)$. Values above $2000 \mu \mathrm{g} / \mathrm{l}$ were measured by extrapolating the standarid curve.

samples demonstrated good linearity up to 1800 $\mu \mathrm{g} / \mathrm{l}$, whereas others deviated from linearity above $500 \mu \mathrm{g} / \mathrm{l}$. The "high dose hook" phenomenon, as described by Miles et al. (6), was not observed in two serum samples with ferritin concentrations of 25000 and $40000 \mu \mathrm{g} / \mathrm{l}$ (fig. 2). In our search for a possible influence of the high dose hook effect we determined 30 serum samples containing ferritin concentrations ranging between 1000 and $2000 \mu \mathrm{g} / \mathrm{l}$ undiluted and diluted $1: 10$. Some representive results are given in table 4. In most cases we observed a deviation from linearity with Spectro Ferritin ${ }^{\circledR}$ and with Fer-iron ${ }^{\circledR}$. However we did not observe a drastic increase of the assay results after dilution, as would be expected if the hook effect were present.

Tab. 4. Ferritin values $(\mu \mathrm{g} / \mathrm{l})$ at two dilutions.

\begin{tabular}{|c|c|c|c|}
\hline \multicolumn{2}{|c|}{ Spectro Ferritin ${ }^{\circledR}$} & \multicolumn{2}{|l|}{ Fer-iron ${ }^{\circledR}$} \\
\hline Undiluted & 11 -fold diluted & Undiluted & 11-fold diluted \\
\hline 1118 & 1694 & 1684 & 1540 \\
\hline 1520 & 2475 & 2367 & 2684 \\
\hline 1114 & 1419 & 1656 & 1430 \\
\hline 1374 & 2453 & 1716 & 2761 \\
\hline 1867 & 2827 & 1386 & 2486 \\
\hline 1472 & 1827 & 1080 & 1848 \\
\hline 2029. & 2882 & 1279 & 2827 \\
\hline 1739 & 2563 & 1508 & 2409 \\
\hline 761 & 1133 & 1085 & n.d. \\
\hline$\gg 2000$ & 6360 & 1924 & 6567 \\
\hline
\end{tabular}

n.d., not determined. 
It is unlikely that the hook effect caused invalid ferritin results below $1000 \mu \mathrm{g} /$, because this would be detected during the sample comparison with the RIA-gnost ${ }^{\circledast s s a y ~(t h e ~ l a t t e r ~ r e q u i r i n g ~ s a m p l e ~ p r e d i-~}$ lution at a low level).

\section{Interference}

Serum samples containing high and low ferritin concentrations and above normal concentrations of possible interfering substances were analysed with the Spectro Ferritin ${ }^{\circledR}$ method.

The following substances do not produce any significant interference: $19 \mathrm{mmol} / \mathrm{l}$ triglycerides, $50 \mathrm{~g} / \mathrm{hu}$ man albumin, $100 \mathrm{~g} / \mathrm{human} \gamma$-globulins, $500 \mu \mathrm{mol} / \mathrm{l}$ bilirubin and $0.05-0.2 \mathrm{mmol} / \mathrm{l}$ haemoglobin.

When we compared the ferritin concentration of EDTA-plasma (7.2 mg of EDTA per $5 \mathrm{ml}$ of blood) with that of serum we observed a decrease of $6 \%$ in the plasma $(n=10 ; p<0.05)$. EDTA-plasma also gives $6 \%$ lower values compared with serum when assayed with the Fer-iron ${ }^{\circledR}$ kit. However we obtained $1 \%$ higher values with EDTA-plasma as compared with serum by using the RIA-gnost ${ }^{\circledR}$ assay. Increasing the EDTA concentrations to $10 \mathrm{~g} / \mathrm{blood}$ has no further influence on these results.

\section{Comparison of methods}

We determined ferritin levels of $1-2000 \mu \mathrm{g} / \mathrm{l}$ in the sera of 127 healthy persons and patients, using the Spectro Ferritin ${ }^{\circledR}$ and the Fer-iron ${ }^{\circledR}$ kits. We did not predilute the sera. Figure 3 illustrates these results. Due to the wide range of the concentrations found, the logarithm of the concentrations were compared.

The sign test and the Wilcoxon matched-pairs test revealed that at a level of $\alpha=0.05$ the Fer-iron ${ }^{\circledR}$ results are significantly higher than those of Spectro Ferritin $^{\circledR}(p=0.01$ and $p<0.0001$ respectively). For concentration ranges of $0-500 \mu \mathrm{g} /$, these tests showed no significant differences between the kits at a level of $\alpha=0.05$ ( $p=0.25$ and $p=0.07$ respectively). A sample comparison of the Spectro Ferri$\operatorname{tin}^{\circledR}$ assay with the RIA-gnost ${ }^{\circledR}$ assay is shown in figure 4 .

\section{Reference values}

In order to establish reference values for the Spectro Ferritin ${ }^{\circledR}$ assay we obtained 190 samples from healthy individuals aged $18-60$ years. Of these

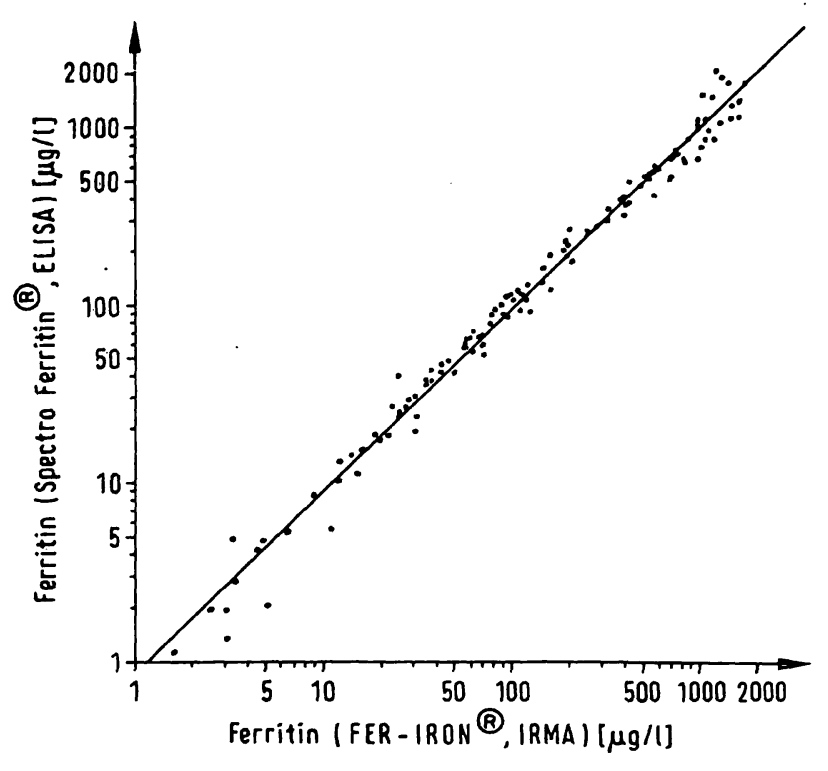

Fig. 3. Comparison of Spectro Ferritin ${ }^{\circledR}$ (ELISA) with Fer-iron ${ }^{\circledR}$ (IRMA). $\mathrm{y}=0.87 \mathrm{x}^{1.01}, \mathrm{r}=0.994, \mathrm{n}=127$.

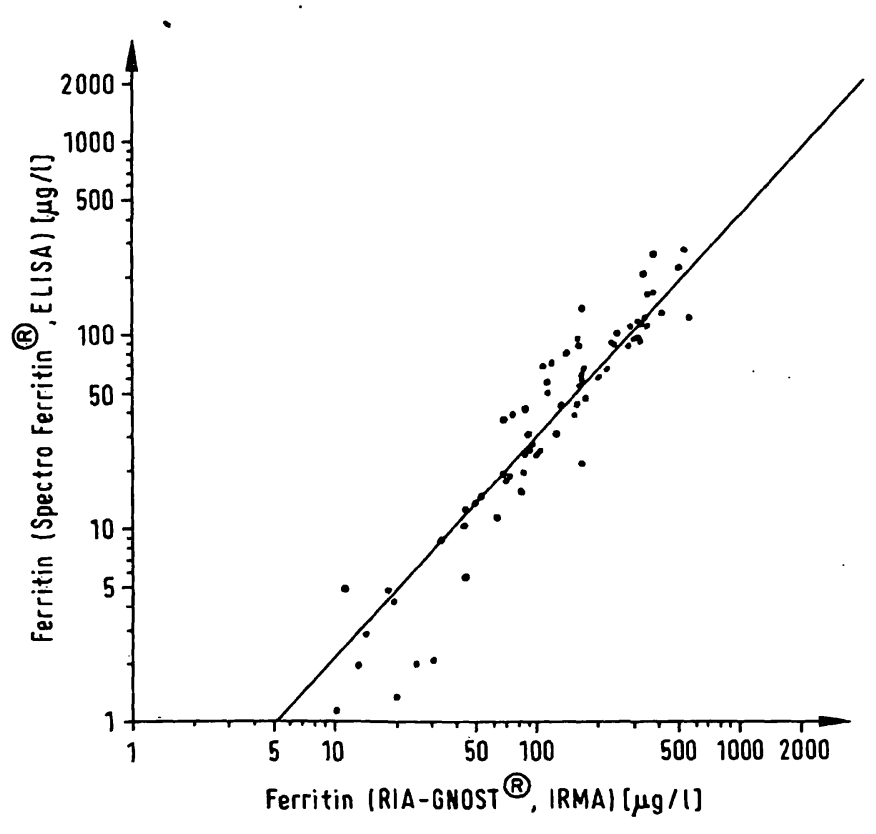

Fig. 4. Comparison of Spectro Ferritin ${ }^{\circledR}$ (ELISA) with RIAgnost $^{\circledR}$ (IRMA). $\mathrm{y}=0.15 \mathrm{x}^{1.15}, \mathrm{r}=0.935, \mathrm{n}=76$

specimens 90 were male and 100 were female. We excluded from this study blood donors or persons who had abnormal levels of serum iron, transferrin or abnormal routine haematological parameters (RBC, Hb, Ht, MCV, MCH, MCHC). The levels found in women were lower than in men and were age dependent (fig. 5). The reference values obtained by the 2.5 th to 97.5 th percentile estimate are shown in table 5 together with the values obtained with the other kits. 


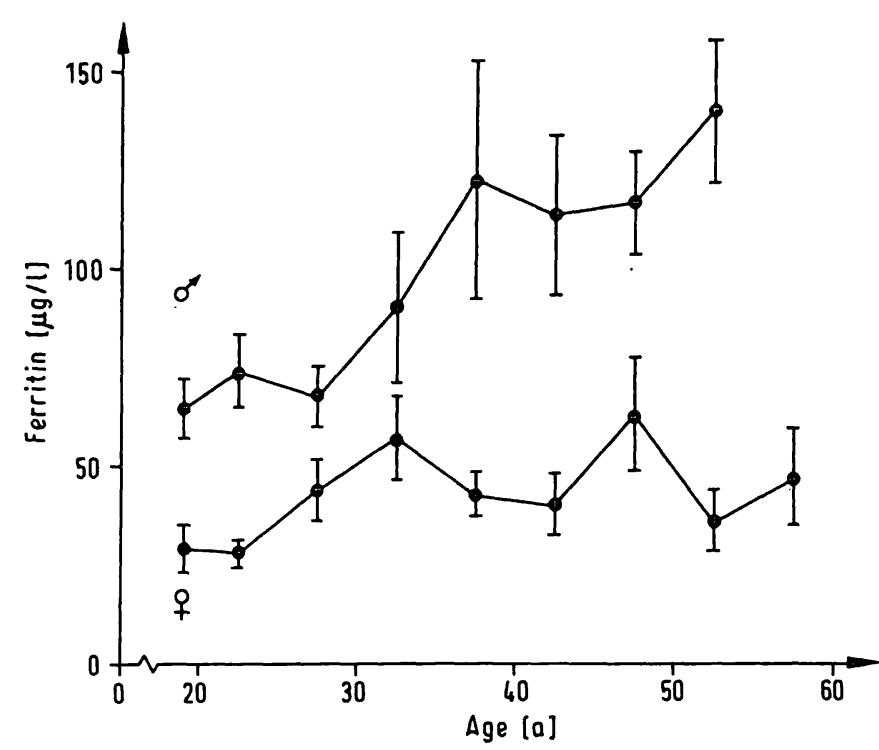

Fig. 5. Age dependency of serum ferritin reference values. Each point represents a 5 -year average \pm SEM.

\section{Discussion}

The Spectro Ferritin ${ }^{\circledR}$ assay (ELISA) is just as practicable as the Fer-iron ${ }^{\circledR}$ assay (IRMA). While the Spectro Ferritin ${ }^{\circledR}$ assay has the advantage that no special precautions have to be taken against radioactive contamination, it does necessitate an extra incubation step of $1 / 2$ hour for the determination of the enzyme activity, producing a total incubation time of 4.5 hours. Another disadvantage of the Spectro Ferritin ${ }^{\circledR}$ kit is the cost. The price per bead is about $12 \%$ higher than those of Fer-iron ${ }^{\circledR}$ and RIA-gnost ${ }^{\circledR}$. It is evident that expensive gamma counting equipment is not required. In our hands the data reduction by logit-log transformation applied better to the Spectro Ferritin ${ }^{\circledR}$ assay than to the RIA-gnost ${ }^{\circledR}$ or Fer-iron ${ }^{\circledR}$ systems, even though the logit-log method is advised for the latter assay. Another great advantage of the Spectro Ferritin ${ }^{\circledR}$ assay is the long shelf life (about 10 months) without detectable stability problems. The sensitivity of Spectro Ferritin ${ }^{\circledR}$ (detection limit: $1.4 \mu \mathrm{g} / \mathrm{l}$ or $14 \mathrm{pg} / \mathrm{bead}$ ) corresponds well with not only those of other ferritin ELISA's $(12.5 \mathrm{pg} /$ tube (10) and $10 \mathrm{pg} /$ tube (11)) but also with that of Feriron ${ }^{\circledR}$ (detection limit: $0.9 \mu \mathrm{g} / 1$ or $9 \mathrm{pg} / \mathrm{bead}$ ). Miles et al. (6) reported for their IRMA a sensitivity of 29 $\mathrm{pg} /$ tube). If we also consider the normal values of ferritin, the detection limit of Spectro Ferritin ${ }^{\circledR}$ seems to be low enough to quantitate ferritin in the serum of patients with iron deficiency.

Based on our precision studies, the Spectro Ferritin ${ }^{\circledR}$ kit works as well as the Fer-iron ${ }^{\circledR}$ method. The with-
Tab. 5. Reference values for serum ferritin.

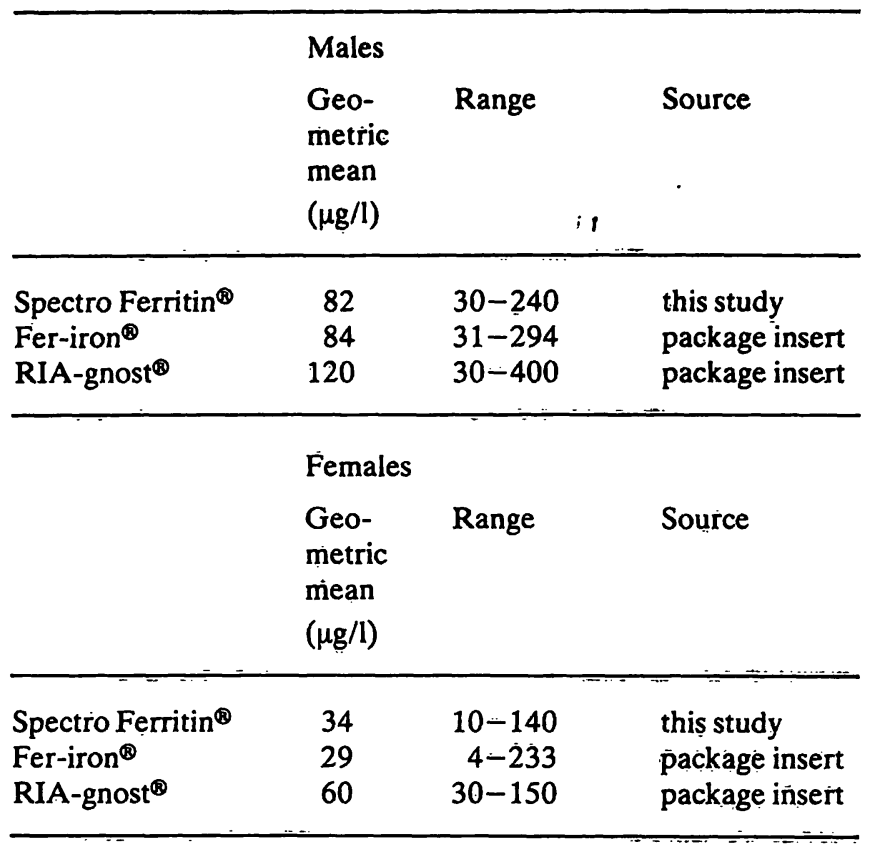

in-run precision for Fer-iron ${ }^{\circledR}$ is slightly better than one observes with Spectro Ferritin ${ }^{\circledR}$, but the between-run precision does not show any great differences in either the normal or low levels (tab. 1). However, we note that the precision of Spectro Ferritin $^{\circledR}$ is better than many other commercial radiometric assays, showing CV's up to $27 \%$ between-run (19).

A general problem of IRMA and ELISA procedures has been the "high dose hook effect", first described by Miles et al. (6). Since the influence of this effect is assay dependent (20-23), one must evaluate this effect for every ELISA or IRMA system. A number of counter measures have been proposed but in practice the quality of a test kit is crucial. In our evaluation of the Spectro Ferritin ${ }^{\circledR}$ assay we found no high dose hook effect up to $40000 \mu \mathrm{g} / \mathrm{l}$ (fig. 2). If we use an upper linearity limit of $1000 \mu \mathrm{g} / \mathrm{l}$, the hook effect is very unlikely to occur and in most cases we do not have to estimate our samples at two dilutions. However, we sometimes observed poor duplications of the results at high concentrations, a phenomenon we also noted with the Fer-iron ${ }^{\circledR}$ kit. It is possible that minor differences in antibody coating of the beads are responsible for this effect.

Ferritin determinations on serial dilutions frequently reveal deviations from linearity above $1000 \mu \mathrm{g} / \mathrm{l}$ (fig. 2, tab. 4). This phenomenon can also be observed using the Fer-iron ${ }^{\circledR}$ kit and agrees with the findings of $L i$ et al. (22). We question their explanation that the nonlinearity is due to the high dose hook effect, 
because the standards and some sera show no deviation up to $2000 \mu \mathrm{g} / \mathrm{l}$ and also because we noted good recoveries up to levels of $1950 \mu \mathrm{g} /$. We recommend diluting and reassaying those serum samples possessing ferritin concentrations above $1000 \mu \mathrm{g} /$.

The influence of EDTA on the ferritin results is inconsistent with reports of other investigators. While some authors found an increase of immunoreactivity (24), or no difference (2), one author found 15$48 \%$ lower values (25). We found $6 \%$ lower ferritin values in EDTA plasma compared with serum using Spectro Ferritin ${ }^{\circledR}$ and Fer-iron ${ }^{\circledR}$. RIA-gnost ${ }^{\circledR}$ gave $1 \%$ higher values for EDTA plasma. It is known that EDTA is capable of releasing iron from ferritin (24) which may cause a structural change in the ferritin molecule, and result in divergent reactivities with different antibodies.

Recently Ghielmi et al. (26) have developed two RIAs an IRMA and two ELISAs for the determination of serum ferritin by using similar antibodies and standard preparations. The ELISAs produced 15\% lower values than the IRMA and were less sensitive (a parameter not quantified). Although Spectro Ferritin ${ }^{\circledR}$ is less sensitive than Fer-iron ${ }^{\circledR}$ we did not observe significant differences in the values obtained (tab. 2, 3). A comparison of various samples (fig. 3) demonstrates significantly lower values for Spectro Ferritin $^{\circledR}$ than with Fer-iron ${ }^{\circledR}$, at levels $>500 \mu \mathrm{g} / 1$, but this difference can be ascribed to the earlier mentioned influence of the logit-log calculation method on the results of Fer-iron ${ }^{\circledR}$. The ferritin values obtained with RIA-gnost ${ }^{\circledR}$ were about 3 times higher than those obtained with the Ramco kits (fig. 4). The lack of international standardization is re- sponsible for the persistence of these differences, although we should not expect identical values using international standards (26). Near the end of our experimental studies Behringwerke unexpectedly changed the nature of their solid phase antibody causing $20-40 \%$ lower ferritin values than observed with earlier kits.

It is our impression that spleen and liver ferritin do not react identically. Sample comparisons of RIAgnost $^{\circledR}$ (liver standards) with Spectro Ferritin ${ }^{\circledR}$ (spleen standards) show that the regression line possesses a slope of about 1.15 (fig. 4). Spleen standards do not parallel liver standards as assayed with the RIA-gnost ${ }^{\circledR}$ kit. Slight differences when using liver and spleen standards have also been reported in the literature $(27,28)$.

The normal values we found correspond very well with those observed with Fer-iron ${ }^{\circledR}$ (23) (tab. 5). Our values do not demonstrate extreme concentrations as compared with other ferritin assays (2). The age dependencies correspond very well with earlier findings (29).

We conclude that the substitution of the radioactive label by an enzyme tag does not reduce the reliability of the ferritin immunoassay.

\section{Acknowledgment}

We thank Laboratorium Service Benelux B.V., the Netherlands, and Ramco Laboratories, USA, for providing the test kits for this study. We would also like to thank the Red Cross Blood Bank of Rotterdam for supplying many blood samples. We are extremely grateful to Ir. $R$. Docter for the use of his data reduction program and to Prof. Dr. H. G. van Eijk for his helpful comments.

\section{References}

1. Alfrey, C. P. (1978) CRC Critical Reviews in Clinical Laboratory Sciences 9, 179-208.

2. Worwood, M. (1979) CRC Critical Reviews in Clinical Laboratory Sciences 10, 171-204.

3. Kaltwasser, J. P. \& Werner, E., eds. (1980) Serumferritin, Methodische und Klinische Aspekte. Springer Verlag, Berlin.

4. Albertini, A., ed. (1980) Radioimmunoassay of Hormones, Proteins and Enzymes, Proceedings of the International Symposium, Gardone Riviera, May 8-10, 1980. Excerpta Medica, Amsterdam, pp. 197-266.

5. Addison, G. M., Beamish, M. R., Hales, C. N., Hodgkin, M., Jacobs, A. \& Llewellin, P. (1972) J. Clin. Pathol. 25, 326329.

6. Miles, L. E. M., Lipschitz, D. A., Bieber, C. P. \& Cook, J. D. (1974) Anal. Biochem. 61, 209-224.

7. Marcus, D. M. \& Zinberg, N. (1975) J. Nat. Cancer Inst. 55, 791-795.

8. Thếriault, L. \& Page, M. (1977) Clin. Chem. 23, 21422144.

9. Zuyderhoudt, F. M. J., Boers, W., Linthorst, C., Jörning, G. G. A. \& Hengeveld, P. (1978) Clin. Chim. Acta 88, 37-44.

10. Watanabe, N., Niitsu, Y., Ohtsuka, S., Koseki, J., Kohgo, Y., Urushizaki, I., Kato, K. \& Ishiwaka, E. (1979) Clin. Chem. $25,80-82$

11. Anaokar, S., Garry, P. J. \& Standefer, J. C. (1979) Clin. Chem. 25, 1426-1431.

12. Pagé, M., Thériault, L. \& Nilsson, M. (1980) Scand. J. Clin. Lab. Invest. 40,641-645.

13. Lee, M. \& Burgett, W. (1981) Clin. Chim. Acta 112, 241246.

14. Anderson, M. G. \& Kelly, A. M. (1981) Clin. Chim. Acta $116,405-408$

15. Fortier, R. L., McGrath, W. P. \& Thomey, S. L. (1979) Clin. Chem. 25, 1466-1469.

16. Thornton, J. A. \& Waters, H. M. (1980) Med. Lab. Sci. 37. $275-283$.

17. Snedecor, G. W. \& Cochran, W. G. (1967) Statistical Methods, The Iowa State University press, Ames, Iowa, USA, 6th ed. pp. $135-171$.

18. Schuurs, A. H. W. M. \& van Weemen, B. K. (1977) Clin. Chim. Acta 81, 1-40.

19. Wood, W. G. (1981) J. Clin. Chem. Clin. Biochem. 19, $947-$ 952. 
20. Green, R., Watson, L. R., Saab, G. A. \& Crosby, W. H. (1977) Blood 50, 545-547.

21. Revenant, M. G. \& Beaudonnet, A. (1982) Clin. Chem. 28, 253-254.

22. Li, P. K., Humbert, J. R. \& Cheng, C. S. (1978) Clin. Chem. 24, 1650-1651.

23. Werner, E. \& Kaltwasser, J. P. (1980) In: Serumferritin, Methodische und Klinische Aspekte (Kaltwasser, J. P. \& Werner, E., eds.) Springer Verlag, Berlin-Heidelberg-New York, pp. 34-55.
24. Porter, F. S. (1974) J. Lab. Clin. Med. 83, 147-152.

25. Birgegard, G. (1980) Clin. Chim. Acta 103, 277-285.

26. Ghielmi, S., Pizżoccolọ, G., Iacobello, C., Albertini, A. \& Arosio, P. (1982) Clin. Chim. Acta 120, 285-294.

27. Mareschal, J. C., Dublet, B., Wustefeld, C., Charlier, E. \& Crichton, R. R. (1981) Clin. Chim. Acta 111, 99-103.

28. Dunn, C. D. R. \& Boden, D. J. (1981) Clin. Chem. 27, 1280-1283. $\cdot 1$

29. Finch, C. A., Cook, J. D., Läbbe, R. F. \& Culala, M. (1977) Blood 50, 441-447.

Drs. H. A. Assink

Centraal klinisch chemisch Laboratorium Academisch Ziekenhuis

Dr. Molewateriplein 40

NL-3015 GD Rotterdam 